\title{
Turkish Linguistic Validation of the Geriatric 8 Screening Tool
}

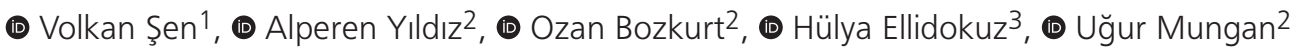 \\ ${ }^{1}$ Manisa City Hospital, Clinic of Urology, Manisa, Turkey \\ 2Dokuz Eylül University Faculty of Medicine, Department of Urology, Izmir, Turkey \\ ${ }^{3}$ Dokuz Eylül University Faculty of Medicine, Department of Biostatistics and Medical Informatics, Izmir, Turkey
}

\begin{abstract}
Objective: To evaluate the Turkish linguistic validation of the Geriatric 8 (G8) screening tool.

Materials and Methods: Professional medical translators independently performed the translation and backtranslation of the original English G8 questionnaire. Patients aged 70 years or older were included in the study. The final Turkish version of the G8 screening tool was administered to all patients, and internal consistency was evaluated using Cronbach's alpha coefficient. The G8 screening tool was administered once more to the patients two weeks after the first administration to evaluate the test-retest reliability. Intraclass correlation coefficient test was used to evaluate the test-retest results. The construct validity of the scale was examined using the exploratory factor analysis.

Results: One hundred and nineteen patients were included in the study. Cronbach's alpha coefficient was 0.72 , which indicated that the screening tool was internally consistent. According to the test-retest analysis, a strong correlation was noted between the test and retest results. When the answers to the same question in the test and retest were compared, they were similar, and this result was consistent with the correlation results.

Conclusion: The Turkish version of the G8 screening tool was established in this study.
\end{abstract}

Keywords: Aging, cancer, geriatrics, questionnaire

\section{Introduction}

Worldwide, it has been noted that the geriatric population has increased and is continuously growing. According to the Turkish Statistical Institute data, the geriatric population (individuals aged 65 years and above) has increased by $17 \%$ between 2013 and 2017 , accounting for $8.5 \%$ of the Turkish population (1). Life expectancy at birth has increased to 81 years in European countries and to 78 years in Turkey (1). Considering the growing older male population in industrialized countries and increasing cancer incidence with aging, the management of elderly patients with cancer has become an important public health problem. Several aspects of the aging process and health status widely vary in older patients. Hence, individual treatment choice is especially important to provide optimal efficacy and minimize toxicity in these patients. Therefore, screening tools have been established to distinguish fit geriatric patients (who can tolerate standard treatments) from frail patients with reversible or irreversible impairments [who need a comprehensive geriatric assessment (CGA)] $(2,3)$. However, most tools have been validated in patients without cancer and evaluated without the side effects of cancer therapy and had to be administered by clinicians $(4,5,6,7,8)$. In 2012, Bellera et al. (9) created the geriatric 8 (G8) screening tool. They showed that G8 had good screening properties for identifying older patients who could benefit from CGA. The G8 screening tool is a self-administered tool consisting of eight items, which evaluate self-perception of health, psychological status, age, weight loss, body mass index, nutritional status of patients, number of medications, and mobility (9). Recently, the G8 screening tool has been used in the treatment of elderly patients with prostate cancer and recommended by the EAU-ESTRO-ESUR-SIOG guidelines on prostate cancer $(2,10,11,12)$. This study aimed to study aimed to evaluate the Turkish linguistic validation of the G8 screening tool.

\section{Materials and Methods}

We contacted the corresponding author and developer of the G8 screening tool, Carine A. Bellera, and obtained permission

Cite this article as: Şen V, Yıldız A, Bozkurt O, Ellidokuz H, Mungan U. Turkish Linguistic Validation of the Geriatric 8 Screening Tool. Bull Urooncol 2021;20(3):133-137

Address for Correspondence: Volkan Şen, Manisa City Hospital, Clinic of Urology, Manisa, Turkey

Phone: +90 5533896859 E-mail: sen_volkan@yahoo.com ORCID-ID: orcid.org/0000-0003-2832-0682 Received: 15.05.2020 Accepted: 27.08.2020 
for a Turkish linguistic validation. The G8 screening tool includes eight items, and the total G8 score ranges from 0 (heavily impaired) to 17 (not at all impaired). It is emphasized that healthy patients with a G8 score greater than 14 and frail patients, who have reversible impairments after the resolution of their geriatric problems with a G8 score of 14 or less, should receive the same definitive treatment as young patients. Patients with a G8 score of 14 or less and who have irreversible geriatric problems should receive symptomatic or palliative treatment.

The Institutional Review Board of Dokuz Eylül University approved the study protocol (decision number: 2019/0243). All patients provided written informed consent. A threestage protocol was used to obtain the Turkish version of the G8 screening tool: translation, internal consistency and content validity, and stability (test-retest reliability).

The First Stage: Two certificated professional Turkish translators independently translated the original English G8 questionnaire (Table 1) into Turkish. The authors checked the translation for medical coherence. Afterwards, two professional medical translators, who did not have access to the original English version, performed a backtranslation of the final document. The original and backtranslated versions of the G8 questionnaire were compared, and a final Turkish version was agreed upon (Table 2).

The Second Stage: Patients who were admitted to our urology outpatient clinic and aged 70 years or older between March 2019 and June 2019 were included in the study. The final Turkish version of the G8 screening tool was administered to all patients, accompanied with a urologist, and internal consistency was evaluated using Cronbach's alpha coefficient.

The Third Stage: The G8 screening tool was administered once more, accompanied with a urologist, to the patients two weeks after the first administration to evaluate the test-retest reliability. The test and retest results of each question in the G8 screening tool were compared.

\section{Statistical Analysis}

Data analysis was performed using IBM Statistical Package for Social Sciences version 25 (IBM Corp., Armonk, NY, USA), and a p-value less than 0.05 was considered statistically significant. In the evaluation of descriptive data, mean \pm standard deviation, median, and $25^{\text {th }}$ and $75^{\text {th }}$ quartile values were used. Item total score correlation and internal consistency (Cronbach's alpha) were used to assess the reliability of the scale, and intraclass correlation coefficient (ICC) was used to evaluate the test-retest results. In the concurrent criterion validity for content validity, the Pearson product-moment correlation coefficient was used. In the investigation of the sample size for the validity of the results obtained from the exploratory factor analysis, KaiserMeyer-Olkin (KMO) and Bartlett's tests were used. Confirmatory factor analysis (CFA) was performed using STATISTICA-12. Root mean square error of approximation (RMSEA) and standard root mean square residual (SRMR) were given as model fit indices.

\section{Results}

One hundred and forty-one patients answered the G8 questionnaire on the first administration. However, 22 patients did not return in the second week of outpatient management and did not complete the retest. Finally, 119 patients were included in the study. The mean age of the patients was $76.72 \pm 5.36$ years. Of these patients, $88.2 \%$ were males and $11.8 \%$ were females. The most common comorbidities were hypertension $(57.1 \%)$ and diabetes mellitus (21.0\%). The majority of the patients had a surgical and smoking history ( $85.7 \%$ and $68.9 \%$, respectively). Cronbach's alpha coefficient was used to evaluate the internal consistency and was 0.72 , which indicated that the screening tool was internally consistent.

The stability of the G8 screening tool was determined by calculating the test and retest reliability using ICC. According to the test-retest analysis, a strong correlation between the test and retest results for each question was noted. When the answers to the same question in the test and retest were compared, they were similar, and this result is consistent with the correlation

\begin{tabular}{|c|c|c|}
\hline & Items & Possible responses (score) \\
\hline \multirow{3}{*}{ A } & \multirow{3}{*}{$\begin{array}{l}\text { Has food intake } \\
\text { declined over the past } \\
3 \text { months due to loss } \\
\text { of appetite, digestive } \\
\text { problems, chewing, or } \\
\text { swallowing difficulties? }\end{array}$} & $0=$ severe decrease in food intake \\
\hline & & $1=$ moderate decrease in food intake \\
\hline & & $2=$ no decrease in food intake \\
\hline \multirow{4}{*}{ B } & \multirow{4}{*}{$\begin{array}{l}\text { Weight loss during the } \\
\text { last } 3 \text { months? }\end{array}$} & $0=$ weight loss $>3 \mathrm{~kg}$ \\
\hline & & $1=$ does not know \\
\hline & & $2=$ weight loss between 1 and $3 \mathrm{~kg}$ \\
\hline & & $3=$ no weight loss \\
\hline \multirow{3}{*}{ C } & \multirow{3}{*}{ Mobility? } & $0=$ bed or chair bound \\
\hline & & $\begin{array}{l}1=\text { able to get out of bed/chair but does } \\
\text { not go out }\end{array}$ \\
\hline & & 2 = goes out \\
\hline \multirow{3}{*}{ E } & \multirow{3}{*}{$\begin{array}{l}\text { Neuropsychological } \\
\text { problems? }\end{array}$} & $0=$ severe dementia or depression \\
\hline & & $1=$ mild dementia \\
\hline & & 2 = no psychological problems \\
\hline \multirow{4}{*}{$\mathbf{F}$} & \multirow{4}{*}{$\begin{array}{l}\text { BMI? (weight in } \mathrm{kg} \text { )/ } \\
\text { (height in } \mathrm{m}^{2} \text { ) }\end{array}$} & $0=\mathrm{BMI}<19$ \\
\hline & & $1=\mathrm{BMI} 19$ to $<21$ \\
\hline & & $2=\mathrm{BMI} 21$ to $<23$ \\
\hline & & $3=\mathrm{BMI} \geq 23$ \\
\hline \multirow{2}{*}{$\mathbf{H}$} & \multirow{2}{*}{$\begin{array}{l}\text { Takes more than three } \\
\text { prescription drugs per } \\
\text { day? }\end{array}$} & $0=$ yes \\
\hline & & $1=$ no \\
\hline \multirow{8}{*}{$\mathbf{P}$} & \multirow{4}{*}{$\begin{array}{l}\text { In comparison with } \\
\text { other people of the } \\
\text { same age, how does } \\
\text { the patient consider } \\
\text { his/her health status? }\end{array}$} & $0.0=$ not as good \\
\hline & & $0.5=$ does not know \\
\hline & & $1.0=$ as good \\
\hline & & $2.0=$ better \\
\hline & \multirow{3}{*}{ Age } & $0:>85$ \\
\hline & & $1: 80-85$ \\
\hline & & $2:<80$ \\
\hline & Total score & $0-17$ \\
\hline
\end{tabular}


results. The test-retest reliability results of the $\mathrm{G} 8$ screening tool are shown in Tables 3 and 4.

In the exploratory factor analysis, $\mathrm{KMO}$ technique is the most commonly used for the sample size's adequacy. The KMO value varies between 0 and 1 , and this value is recommended to be greater than 0.60 . Bartlett's test of sphericity tests whether the data are from a multivariate normal distribution. In this study, the KMO test result was 0.647 , and Bartlett's test was 163.262 $(p<0.001)$. According to these results, it was found that the data came from multiple normal distributions, and the sample size was sufficient and suitable for factor analysis. To validate the construct validity in the Turkish adaptation of the G8 screening tool, CFA was used because of the one-dimensional structure. CFA based on the theoretical background showed acceptable fit for the G8 screening tool $\left[\chi^{2}(20)=37.209, p=0.011\right.$; RMSEA $=0.084$, $95 \%$ confidence interval (0.039-0.127); SRMR $=0.082(13)]$.

\begin{tabular}{|c|c|c|}
\hline & Maddeler & Olası yanıtlar (puan) \\
\hline \multirow{3}{*}{ A } & \multirow{3}{*}{$\begin{array}{l}\text { İştahsızlık, sindirim } \\
\text { problemleri, çiğneme } \\
\text { veya yutma güçlüğü } \\
\text { nedeniyle gıda alımı } \\
\text { son } 3 \text { ayda azaldı mı? }\end{array}$} & $0=$ besin alımında ciddi azalma \\
\hline & & $1=$ besin alımında orta düzeyde azalma \\
\hline & & 2 = besin alımında azalma yok \\
\hline \multirow{4}{*}{ B } & \multirow{4}{*}{ Son 3 aydaki kilo kaybı? } & $0=$ kilo kaybı $>3 \mathrm{~kg}$ \\
\hline & & 1 = bilmiyor \\
\hline & & $2=1$ ile $3 \mathrm{~kg}$ arasında kilo kaybı \\
\hline & & $3=$ kilo kaybı yok \\
\hline \multirow{3}{*}{ C } & \multirow{3}{*}{ Hareketlilik? } & 0 = yatağa ya da sandalyeye bağlı \\
\hline & & $\begin{array}{l}1 \text { = yataktan/sandalyeden kalkabiliyor, } \\
\text { ancak dışarı çıkmıyor }\end{array}$ \\
\hline & & $2=$ dışarı çıkıyor \\
\hline \multirow{3}{*}{ E } & \multirow{3}{*}{ Nöropsikolojik sorunlar? } & $0=$ şiddetli demans ya da depresyon \\
\hline & & $1=$ hafif demans \\
\hline & & 2 = psikolojik sorunları yok \\
\hline \multirow{4}{*}{$\mathrm{F}$} & \multirow{4}{*}{$\begin{array}{l}\text { VKi? }(\mathrm{kg} \text { cinsinden } \\
\text { ağırlık)/( } \mathrm{m}^{2} \text { cinsinden } \\
\text { boy) }\end{array}$} & $0=\mathrm{VKI}<19$ \\
\hline & & $1=$ VKI 19 ile $<21$ arası \\
\hline & & $2=$ VKi 21 ile $<23$ arası \\
\hline & & $3=\mathrm{VKI} \geq 23$ \\
\hline \multirow{2}{*}{$\mathrm{H}$} & \multirow{2}{*}{$\begin{array}{l}\text { Günde üçten fazla } \\
\text { reçeteli ilaç alıyor mu? }\end{array}$} & $0=$ evet \\
\hline & & $1=$ hayır \\
\hline \multirow{8}{*}{$P$} & \multirow{4}{*}{$\begin{array}{l}\text { Aynı yaştaki } \\
\text { diğer insanlarla } \\
\text { karşılaştırılı̆ı̆ında hasta } \\
\text { sağlık durumunu nasıl } \\
\text { değerlendirir? }\end{array}$} & 0.0 = diğerleri kadar iyi değil \\
\hline & & $0.5=$ bilmiyor \\
\hline & & 1.0 = diğerleri kadar iyi \\
\hline & & $2.0=$ diğerlerinden daha iyi \\
\hline & \multirow{3}{*}{ Yaş } & $0:>85$ \\
\hline & & 1: $80-85$ \\
\hline & & $2:<80$ \\
\hline & Toplam skor & $0-17$ \\
\hline
\end{tabular}

\begin{tabular}{|c|c|c|c|c|c|}
\hline & $\begin{array}{l}\text { Test } \\
\text { mean } \pm S D \\
\text { median }\left(Q_{1}-Q_{3}\right)\end{array}$ & $\begin{array}{l}\text { Retest } \\
\text { mean } \pm S D \\
\text { median } \\
\left(Q_{1}-Q_{3}\right)\end{array}$ & $p$-value & ICC & $95 \% \mathrm{Cl}$ \\
\hline$A$ & $\begin{array}{l}1.92 \pm 0.30 \\
2(2-2)\end{array}$ & $\begin{array}{l}1.92 \pm 0.33 \\
2(2-2)\end{array}$ & 0.317 & 0.958 & $0.940-0.970$ \\
\hline B & $\begin{array}{l}2.76 \pm 0.78 \\
3(3-3)\end{array}$ & $\begin{array}{l}2.76 \pm 0.78 \\
3(3-3)\end{array}$ & 1.000 & 1.000 & $1.000-1.000$ \\
\hline C & $\begin{array}{l}1.93 \pm 0.31 \\
2(2-2)\end{array}$ & $\begin{array}{l}1.93 \pm 0.31 \\
2(2-2)\end{array}$ & 1.000 & 1.000 & $1.000-1.000$ \\
\hline$E$ & $\begin{array}{l}2.01 \pm 0.09 \\
2(2-2)\end{array}$ & $\begin{array}{l}2.01 \pm 0.09 \\
2(2-2)\end{array}$ & 1.000 & 1.000 & $1.000-1.000$ \\
\hline $\mathrm{F}$ & $\begin{array}{l}2.88 \pm 0.47 \\
3(3-3)\end{array}$ & $\begin{array}{l}2.88 \pm 0.47 \\
3(3-3)\end{array}$ & 1.000 & 1.000 & $1.000-1.000$ \\
\hline $\mathrm{H}$ & $\begin{array}{l}0.77 \pm 0.42 \\
1(1-1)\end{array}$ & $\begin{array}{l}0.77 \pm 0.42 \\
1(1-1)\end{array}$ & 1.000 & 1.000 & $1.000-1.000$ \\
\hline$P$ & $\begin{array}{l}1.18 \pm 0.72 \\
1(1-2)\end{array}$ & $\begin{array}{l}1.17 \pm 0.70 \\
1(1-2)\end{array}$ & 0.739 & 0.956 & $0.937-0.969$ \\
\hline Age & $\begin{array}{l}1.64 \pm 0.62 \\
2(1-2)\end{array}$ & $\begin{array}{l}1.64 \pm 0.62 \\
2(1-2)\end{array}$ & 1.000 & 1.000 & $1.000-1.000$ \\
\hline $\begin{array}{l}\text { Total } \\
\text { score }\end{array}$ & $\begin{array}{l}15.10 \pm 1.95 \\
14(14-16)\end{array}$ & $\begin{array}{l}15.09 \pm \\
1.95 \\
14(14-16)\end{array}$ & 0.470 & 0.993 & $0.990-0.995$ \\
\hline \multicolumn{6}{|c|}{$\begin{array}{l}\text { ICC: Intraclass correlation coefficient, Wilcoxon signed-rank test, Cl: Confidence } \\
\text { interval, SD: Standard deviation }\end{array}$} \\
\hline
\end{tabular}

\begin{tabular}{|l|l|l|l|l|l|l|l|l|}
\hline \multicolumn{7}{|c|}{ Table 4. Correlation values of the G8 screening tool } \\
\hline & A & B & C & E & F & H & P & Age \\
\hline A & 1 & & & & & & & \\
\hline B & 0.769 & 1 & & & & & & \\
\hline C & 0.312 & 0.249 & 1 & & & & & \\
\hline E & 0.024 & 0.028 & 0.020 & 1 & & & & \\
\hline F & 0.239 & 0.316 & 0.003 & 0.023 & 1 & & & \\
\hline H & -0.003 & 0.146 & 0.012 & -0.170 & -0.050 & 1 & & \\
\hline P & 0.043 & 0.121 & 0.243 & -0.023 & -0.013 & 0.190 & 1 & \\
\hline Age & 0.035 & 0.138 & 0.224 & 0.054 & -0.031 & 0.138 & 0.144 & 1 \\
\hline Pearson product-moment correlation coefficient & & & \\
\hline
\end{tabular}

\section{Discussion}

Recently, there has been an increase in the elderly population; this increase changed patients' management and became a major health problem. CGA is the gold-standard method for evaluating the health status of elderly patients. CGA is a multidimensional, interdisciplinary diagnostic process used for determining the functional, psychological, and medical capabilities of frail older patients to establish a coordinated and integrated plan for treatment and follow-up. CGA is part of oncologic care to assess the overall health status of older patients; however, it is time-consuming and requires a specialist staff. Therefore, various screening tools, including the G8, have been used to determine which patients need CGA before treatment decision $(4,5,6,7,8,9)$. The $G 8$ is the first screening tool designed specifically for older patients with cancer to distinguish fit patients from frail ones (9). Several validation studies, including 
those on patients with cancer, have been published, with G8 being one of the most robust screening tools currently available in systematic reviews $(11,12,14,15,16,17,18,19)$. Moreover, it was noted that the $\mathrm{G} 8$ screening tool could be used in predicting the prognosis and overall survival (OS) in several types of cancer $(14,15,16)$. Agemi et al. (14) investigated the role of the G8 screening tool in predicting the OS and clinical outcomes in older patients with lung cancer, who received chemotherapy or chemoradiotherapy, and they found that a low G8 score was significantly associated with poor OS. They emphasized that the G8 screening tool was as useful as the Eastern Cooperative Oncology Group performance status in predicting the prognosis of older patients with lung cancer and can be used in preventing patients from receiving inappropriate anticancer treatment (14). Deluche et al. (15) designed a study to validate the G8 screening tool and evaluate its role in predicting OS in elderly patients with glioblastoma. They noted that the G8 screening tool could effectively distinguish healthy patients from frail ones (15). Sakurai et al. (16) evaluated the role of the G8 screening tool in survival outcomes in elderly patients with diffuse large B-cell lymphoma. They showed that, in these patients, a low G8 score is an independent risk factor for poor prognosis and OS.

Most urological cancers are detected in advanced ages, and the treatment choices depend on the patient's age and health status. Few reports on the feasibility of the G8 screening tool in elderly patients with urological cancer are available in the literature $(20,21,22)$. Prostate cancer is the most frequently occurring cancer in men, with a median age at diagnosis of 68 years $(10,23)$. It is expected that there will be a $70 \%$ increase in the annual diagnoses in men above 65 years of age by 2030 in Europe and the USA $(23,24)$. In localized disease, a life expectancy of more than 10 years requires a local definitive treatment. Patients with a moderate- or high-risk prostate cancer with a long life expectancy can benefit from active definitive treatment regimens (10). A poor baseline health status is associated with less benefit from definitive treatment regimens, including surgery, radiotherapy, and active surveillance in patients with prostate cancer. While definitive treatment regimens do not increase the life expectancy of patients with worse baseline health status, increased morbidity negatively affects patients' quality of life. Watchful waiting, including symptomatic or palliative treatment, is more appropriate for this group of patients. Thus, it is important to evaluate the baseline health status (fit or frail) in elderly patients with prostate cancer. The International Society of Geriatric Oncology Prostate Cancer Working Group recommends that treatment for senior adults should be based on a systematic evaluation of health status using the G8 screening tool (21), and this recommendation has been included in the EAU 2017 guidelines on prostate cancer (10). Moreover, in a recent publication, Beardo et al. (22) investigated the safety and outcomes of new-generation hormonal therapy (NGHT) (enzalutamide and abiraterone acetate) in elderly chemotherapy-naïve metastatic castrationresistant patients with prostate cancer and concluded that the G8 screening tool could help identify patients aged 75 years or older who would most benefit from NGHT. The results of this study showed that the G8 screening tool can be used at different points of treatment decision in elderly patients with prostate cancer. There is one study in which the use of the G8 screening tool in patients with bladder cancer was investigated. Maebayashi et al. (20) evaluated using the G8 screening tool to determine whether to add intra-arterial chemotherapy (IAC) to radiotherapy in elderly patients with muscle-invasive bladder cancer and found that the G8 screening tool was potentially applicable in determining the feasibility of adding IAC in these patients.

\section{Conclusion}

The G8 screening tool is an easy and ideal screening tool, which requires less time to perform, covers all domains routinely evaluated by geriatricians, and effectively separates fit patients from frail ones. In this study, the Turkish version of the G8 screening tool was obtained and validated. We believe that this Turkish version of the G8 screening tool can be used in deciding the treatment options for elderly patients in daily clinical practice.

\section{Acknowledgements}

Publication: This study was presented in the $14^{\text {th }}$ International Urooncology Congress on November 6-10 in 2019, Antalya, Turkey.

Contribution: The authors thank Busra Emir and Ferhan Elmali for their contribution to the statistical analysis of the manuscript.

Conflict of Interest: No conflict of interest was declared by the authors.

Financial Disclosure: The authors declared that this study received no financial support.

\section{Ethics}

Ethics Committee Approval: The Institutional Review Board of Dokuz Eylül University approved the study protocol (decision number: 2019/02-43).

Informed Consent: All patients provided written informed consent.

Peer-review: Externally peer-reviewed.

\section{Authorship Contributions}

Concept: V.Ş., H.E., U.M., Design: V.Ş., O.B., H.E., U.M., Data Collection or Processing: V.Ş., A.Y., Analysis or Interpretation: H.E., Literature Search: V.Ş., A.Y., Writing: V.Ş.

\section{References}

1. Turkish Statistical Instutute. Life tables 2015-2017. Last Accessed Date: 25.10.2019. Available from: http://www.tuik.gov.tr/UstMenu. do?metod=temelist.

2. Martinez-Tapia C, Canoui-Poitrine F, Bastuji-Garin S, et al; ELCAPA Study Group. Optimizing the g8 screening tool for older patients with cancer: diagnostic performance and validation of a six-item version. Oncologist 2016;21:188-195.

3. Decoster L, Van Puyvelde K, Mohile S, et al. Screening tools for multidimensional health problems warranting a geriatric assessment in older cancer patients: an update on SIOG recommendationst. Ann Oncol 2015;26:288-300. 
4. Lachs MS, Feinstein AR, Cooney LM Jr, et al. A simple procedure for general screening for functional disability in elderly patients. Ann Intern Med 1990;112:699-706.

5. Winograd $\mathrm{CH}$, Gerety $\mathrm{MB}$, Chung $\mathrm{M}$, et al. Screening for frailty: criteria and predictors of outcomes. J Am Geriatr Soc 1991;39:778-784.

6. Gill TM, Williams CS, Tinetti ME. Assessing risk for the onset of functional dependence among older adults: the role of physical performance. J Am Geriatr Soc 1995;43:603-609.

7. Brody KK, Johnson RE, Douglas RL. Evaluation of a self-report screening instrument to predict frailty outcomes in aging populations. Gerontologist 1997;37:182-191.

8. Rockwood K, Stadnyk K, Mac Knight C, et al. A brief clinical instrument to classify frailty in elderly people. Lancet 1999;353:205-206.

9. Bellera CA, Rainfray M, Mathoulin-Pélissier S, et al. Screening older cancer patients: first evaluation of the G-8 geriatric screening tool. Ann Oncol 2012;23:2166-2172.

10. Mottet N, Bellmunt J, Bolla M, et al. EAU-ESTRO-SIOG Guidelines on Prostate Cancer. Part 1: screening, diagnosis, and local treatment with curative Intent. Eur Urol 2017;71:618-629.

11. Velghe A, Petrovic M, De Buyser S, et al. Validation of the $g 8$ screening tool in older patients with aggressive haemotological malignancies. Eur J Oncol Nurs 2014;18:645-8.

12. Soubeyran P, Bellera C, Goyard J, et al. Screening for vulnerability in older cancer patients: the ONCODAGE Prospective Multicenter Cohort Study. PloS One 2014;9:e115060. doi: 10.1371/journal. pone.0115060.

13. Curran PJ, Bollen KA, Chen F, et al. Finite sampling properties of the point estimates and confidence intervals of the RMSEA. Sociol Methods Res 2003;32:208-252.

14. Agemi Y, Shimokawa T, Sasaki J, et al. Prospective evaluation of the G8 screening tool for prognostication of survival in elderly patients with lung cancer: A single-institution study. PLoS One 2019;14:e0210499. doi: 10.1371 /journal.pone.0210499.

15. Deluche E, Leobon S, Lamarche F, et al. First validation of the G-8 geriatric screening tool in older patiens with glioblastoma. J Geriatr Oncol 2019;10:159-163.
16. Sakurai $M$, Karigane $D$, Kasahara $H$, et al. Geriatric screening tools predict survival outcomes in older patients with diffuse large B cell lymphoma. Ann Hematol 2019;98:669-678.

17. Hamaker ME, Jonker JM, de Rooij SE, et al. Frailty screening methods for predicting outcome of a comprehensive geriatric assessment in elderly patients with cancer: a systematic review. Lancet Oncol 2012;13:e437-e444. doi: 10.1016/S1470-2045(12)70259-0.

18. Decoster L, Van Puyvelde K, Mohile S, et al. Screening tools for multidimensional health problems warranting a geriatric assessment in older cancer patients: an update on SIOG recommendations $\dagger$. Ann Oncol 2015;26:288-300.

19. van Walree IC, Scheepers E, van Huis-Tanja LH, et al. A systematic review on the association of the G8 with geriatric assessment, prognosis and course of treatment in older patients with cancer. J Geriatr Oncol 2019;10:847-858.

20. Maebayashi T, Ishibashi N, Aizawa T, et al. Radiotherapy for muscleinvasive bladder cancer in very elderly patients. Anticancer Res 2016;36:4763-4769.

21. Droz JP, Albrand G, Gillessen S, et al. Management of prostate cancer in elderly patients: recommendations of a task force of the International Society of Geriatric Oncology. Eur Urol 2017;72:521-531.

22. Beardo P, Osman I, San José B, et al. Safety and outcomes of new generation hormone-therapy in elderly chemotherapy-naive metastatic castration-resistant prostate cancer patients in the real world. Arch Gerontol Geriatr 2019;82:179-185.

23. Smith BD, Smith GL, Hurria A, et al. Future of cancer incidence in the United States: burdens upon an aging, changing nation. J Clin Oncol 2009;27:2758-2765.

24. Arnold M, Karim-Kos HE, Coebergh JW, et al. Recent trends in incidence of five common cancers in 26 European countries since 1988: Analysis of the European Cancer Observatory. Eur J Cancer 2015;51:1164-1187. 